\title{
Status of the Pear Industry in Africa, with Specific Reference to South Africa
}

\author{
C.H. Ferrandi ${ }^{1}$, P.W. van der Merwe ${ }^{1}$ and M. Huysamer ${ }^{2}$ \\ ${ }^{1}$ Frudata \\ ${ }^{2}$ Department of Horticultural Science \\ PO Box 1894 \\ Somerset West \\ 7129 \\ University of Stellenbosch \\ Private Bag X1, Matieland \\ South Africa \\ 7602 \\ South Africa
}

Keywords: Pyrus communis, yield, cultivars, rootstocks, planting densities, crop utilisation

\begin{abstract}
In the context of global production, Africa as a continent is a very small producer of Pyrus communis pears, with roughly $3 \%$ of global hectares and production. South Africa produces $56 \%$ of Africa's total crop, followed by Algeria $(16 \%)$, Tunisia $(11 \%)$, Egypt $(9 \%)$ and Morocco $(8 \%)$. With the exception of very small volumes at high elevations in Kenya and Zimbabwe, production is located around $33-35^{\circ}$ north and south of the equator. Since the early 1980 's, plantings in South Africa have increased from approximately 7000 to 13000 hectares. The main cultivars are 'Packham's Triumph', 'Bon Chrétien', 'Forelle', 'Rosemarie' and 'Beurre Bosc'. Planting densities have increased from 740 trees per hectare in 1980 to an average of 1746 trees per hectare in 1995. Roughly $45 \%$ of the current orchards are on clonal BP1 and BP3 rootstocks with the remaining, mainly older, orchards on seedling rootstocks. About $38 \%$ of the production is packed for export, $44 \%$ used for processing (canning and juice) and $18 \%$ for local fresh market consumption. Exports have increased from approximately 6 million cartons $(\mathbf{1 2 . 5}$ kg) in 1990 to 10 million cartons in 2003. The continental EU accounts for approximately $45 \%$ of exports, followed by the United Kingdom (41\%), Far East $(8 \%)$, North America (3\%), Middle East (2\%) and Africa (1\%). The pear industry in South Africa experienced a 'golden era' in the early 1990's, but has since been struggling to maintain profitability, primarily due to exchange rate fluctuations and the overall worldwide market negativity for deciduous fruit.
\end{abstract}

\section{PEAR PRODUCTION IN AFRICA}

In the context of global production, Africa is a very small producer of European pears (Pyrus communis L.) with roughly 3\% of global plantings and production (Table 1). In the period 1998-2002, African hectares under pears increased by $10.7 \%$ as opposed to $19.7 \%$ globally. Corresponding yield increased by $20.1 \%$ and $12.4 \%$, respectively. With the possible exception of table grapes and some low-chill stone fruit that are grown in a number of African countries, albeit not extensively, deciduous fruit production is concentrated in the Mediterranean climates of northern and southern Africa. Within this fruit type, the European pear has a very limited distribution. On the African continent, South Africa is by far the largest producer, with $56 \%$ of the total production (averaged over the period 1998-2002). Algeria (16\%), Tunisia (11\%), Egypt (9\%) and Morocco $(8 \%)$ make up the bulk of the remainder, with Madagascar, Libya, Zimbabwe and Kenya combined at less than $1 \%$ of the continent's production. In the case of Kenya and Zimbabwe, production is limited to areas receiving adequate winter chilling by virtue of elevation. 


\section{PEAR PRODUCTION IN SOUTH AFRICA}

\section{Hectares and Cultivars}

The number of hectares of European pears planted in South Africa increased by 84\% from 7011 in 1980 to 12911 in 2002 (Table 2). The greatest increment occurred between 1980 and 1985, when plantings increased by 35\%. Since a 19\% increase in the period 1990 to 1995, there have been few new orchards established, and plantings are mostly replacement blocks for old pear orchards.

On a hectare basis, the cultivar mix is dominated by 'Bon Chrétien' (30\%) and 'Packham's Triumph' (28\%) (Table 3). The former cultivar serves a dual purpose as both fresh and processing cultivar, and in terms of fresh product 'Packham's Triumph' has the largest volume. There has been much emphasis on the blushed cultivars like 'Forelle', 'Rosemarie' and 'Flamingo' over the past 15 years, with high returns to growers, particularly from 'Forelle'. The absence of fireblight has meant that South Africa has a relative advantage over competitors in fireblight-susceptible cultivars like 'Forelle'.

\section{Rootstocks, Planting Densities and Training Systems}

Up to the mid 1980's, most orchards were established on pear seedling rootstocks. However, since then the clonal BP1 and BP3 rootstocks have dominated, with smaller quantities (mainly experimental) on quince stocks. It is estimated that approximately $45 \%$ of the current 12912 hectares of pears are on BP1 and BP3 rootstocks. The remainder, consisting of mostly older blocks, are still on seedling.

Planting densities have followed the same trends as in other pear producing countries internationally, namely a move towards higher density plantings. This is evident when comparing the average tree densities in 1980 (740 trees per hectare) with the average in 1995 (1 746 trees per hectare) (Table 2). This trend has been driven by the introduction of the clonal rootstocks that impart a degree of vigour control and precocity, but also by advances in tree training and pruning technology that allow earlier cropping. Most orchards are now established with a between-row spacing of 4-4.5 $\mathrm{m}$ and a withinrow spacing of $1.5-2 \mathrm{~m}$. Trees are still predominantly trained to a free-standing central leader or spindle system and pruning inputs are based on the specific bearing habit of the cultivar.

\section{Crop Utilisation}

Although the pear industry in South Africa is very much export driven, only about $38 \%$ of the total crop is exported in a fresh form (Fig. 1). This is partly due to the large volume of 'Bon Chrétien' (30\% of the total crop), of which a significant percentage is processed. Other reasons include a fairly high percentage cull for various reasons, including sunburn, size (too small and too large) and lack of adequate colour in the blushed cultivars. In comparison to apples, where there has been a steady decline in the percentage exported, the pears have maintained a fairly constant export percentage. This is an indication of the greater constraints facing apple producers in South Africa, where a combination of soil limitations, climatic factors like inadequate winter chill units and a high incidence of sunburn as well as more stringent market specifications have caused a declining export percentage. Approximately $44 \%$ of the crop is processed and $18 \%$ sold fresh domestically (Fig. 1). Fresh pear consumption has increased steadily in South Africa in the past decade, from approximately $1.2 \mathrm{~kg}$ per capita in $1995-1997$ to $1.66 \mathrm{~kg}$ per capita in 2000-2002.

In terms of exports, the industry has experienced an upward trend since 1991, when about 6 million cartons $(12.5 \mathrm{~kg})$ were exported. The corresponding figure in 2003 was approximately 10 million cartons (Fig. 2). The main export destinations in 2003 were the continental European Union (45\%), United Kingdom (41\%), Far East (8\%), North America (3\%), Middle East (2\%) and Africa (1\%). 


\section{CONCLUSION}

The South African pear industry remains an important sector of the deciduous fruit industry, but is equally negatively affected by the market forces impacting on the apple, stone fruit and table grape industries. The period from 1985 to 1992 was relatively profitable, but since then there have been inconsistent returns due to various factors such as exchange rate fluctuations, new labour legislation and upheaval in export marketing with deregulation of the industry in 1997. Nevertheless, the industry is fundamentally sound and technically well qualified to compete internationally.

\section{ACKNOWLEDGEMENTS}

The authors gratefully acknowledge the contributions of Daan Strydom, Chris Jurisch and Christo Strydom, who provided valuable insights into some of the technical aspects of pear production.

\section{Tables}

Table 1. Global plantings and production of European pears (Pyrus communis L.). Figures in parentheses indicate Africa's contribution as a percentage of global plantings and production. Source: FAO.

\begin{tabular}{ccccc} 
& \multicolumn{2}{c}{ Hectares } & \multicolumn{2}{c}{ Production (tonnes) } \\
\cline { 2 - 5 } Year & World & Africa & World & Africa \\
\hline 1998 & 1487516 & $43647(2.9)$ & 15223755 & $441701(2.9)$ \\
1999 & 1540839 & $46024(3.0)$ & 15657212 & $513065(3.3)$ \\
2000 & 1594699 & $46995(2.9)$ & 16756405 & $512649(3.1)$ \\
2001 & 1591588 & $47616(3.0)$ & 16707008 & $477651(2.9)$ \\
2002 & 1780473 & $48322(2.7)$ & 17115205 & $530547(3.1)$ \\
\hline
\end{tabular}

Table 2. Number of hectares and planting densities of European pears in South Africa.

Source: South African Apple and Pear Producers'Association.

\begin{tabular}{ccc} 
Year & Hectares & $\begin{array}{c}\text { Planting density } \\
\text { (trees/hectare) }\end{array}$ \\
\hline 1980 & 7011 & 740 \\
1985 & 9480 & 940 \\
1990 & 10103 & 1192 \\
1995 & 11975 & 1746 \\
2000 & 12700 & - \\
2002 & 12911 & - \\
\hline
\end{tabular}

Table 3. The South African pear cultivar mix, on a hectare basis. Figures in parentheses indicate percentage contribution to the total. Source: Deciduous Fruit Producers' Trust.

\begin{tabular}{lc} 
Cultivar & Hectares \\
\hline Bon Chrétien & $3884(30.1)$ \\
Packham's Triumph & $3618(28.0)$ \\
Forelle & $2048(15.9)$ \\
Rosemarie & $662(5.1)$ \\
Beurre Bosc & $644(5.0)$ \\
Doyenne du Comice & $431(3.3)$ \\
Other & $1625(12.6)$ \\
Total & $12912(100)$ \\
\hline
\end{tabular}




\section{Figures}

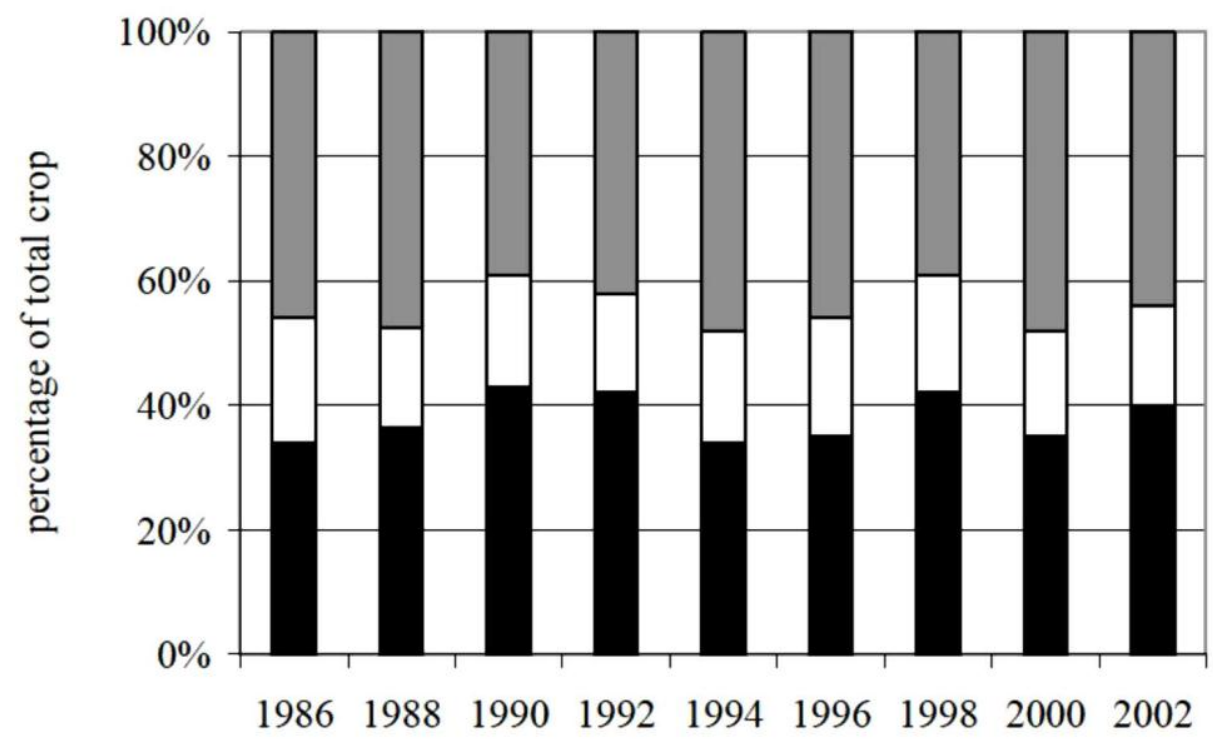

Export $\square$ Domestic $\square$ Processing

Fig. 1. Utilisation of the South African pear crop between 1986 and 2002. Source: South African Apple and Pear Producers' Association and Deciduous Fruit Producers' Trust.

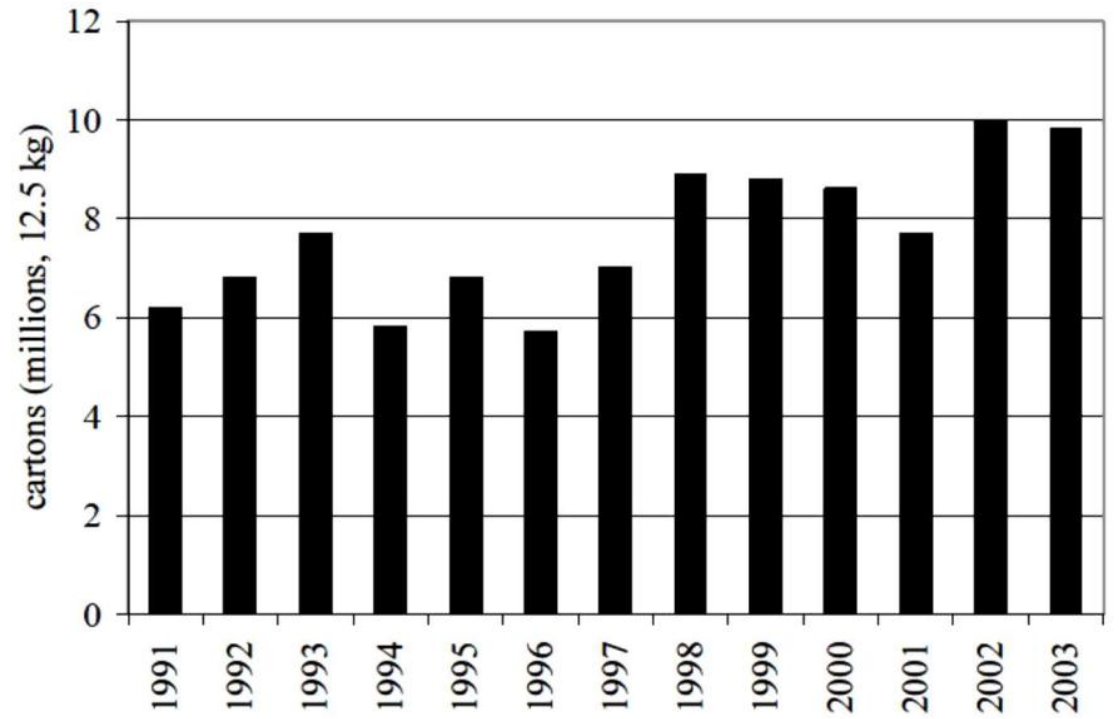

Fig. 2. Exports of South African pears from 1991 to 2003, in millions of cartons (12.5 kg). Sources: Unifruco (1991-1997), Perishable Products Export Control Board (1998-2003). 